\title{
Fundamental factor of financial management in determining company values
}

\author{
Yuniningsih Yuniningsih ${ }^{a^{*}}$, Tri Kartika Pertiwi ${ }^{a}$ and Eko Purwanto ${ }^{a}$
}

${ }^{a}$ Faculty of Economic and Business, Universitas Pembangunan Nasional "Veteran" Jawa Timur, Indonesia

\begin{tabular}{l}
\hline C H R O N I C L E \\
\hline Article history: \\
Received: October 26, 2018 \\
Received in revised format: No- \\
vember 28, 2018 \\
Accepted: December 5, 2018 \\
Available online: \\
December 5, 2018 \\
\hline Keywords: \\
Interdependence \\
Leverage \\
Investment \\
Dividend \\
Company Value
\end{tabular}

\section{A B S T R A C T}

Financial management faces 3 important decisions, namely funding, investment and dividends. The purpose of this study is to determine the effects of the fundamental factors such as leverage in financial management. Leverage is one of the factors of funding, investment and dividends that interdependently affect the value of the company. The method used in this study uses 2SLS (twostage least square). There are 4 (four) equations in this study, namely the equation of leverage, investment, dividend and company value. Interdependence is shown based on leverage, investment and dividends. In the interdependence equation leverage, investment and dividends not only on one side act as endogenous variables but also act as exogenous variables on the equation of the company values. The results of the research on leverage equations show that investment affects leverage but dividends do not affect leverage. The investment equation shows the results of both leverage and dividend variables would not affect investment decision. Dividend equation also shows that leverage and investment variables also do not affect dividends. Moreover, the results of the company value equation show that the leverage variable would not affect the value of the company. But investment and dividend variables affect the value of the company. The conclusion of this study is that there was a mutually influential relationship between the three variables of financial management before influencing company value.

\section{Introduction}

Any firm in the world tries to establish short-term and long-term objectives. Short term objectives are used for profit maximization while long-term objectives are considered for maximizing company value (Nwamaka, 2017). The company's goal is to maximize stakeholders' wealth, by maximizing the value of the company. The company value is the actual value per share, which would be received if the company's assets are sold according to the stock price (Zutter \& Gitman, 2011). The value of a company that goes public is based on the value of the stock price (Hasna et al., 2018; Yuniningsih et al., 2018). Meanwhile, according to Modigliani and Miller (1958) and Nwamaka (2017), the higher the asset income, the higher the value of the company. The Jakarta Islamic Index (JII) consists of 30 selected stocks used as benchmarks in measuring the investment performance of companies. According to Beik and Fatmawati (2014) stocks selected in JII are expected to increase investors' trust in investing according to Islamic principles. Investors consider factors such as firms' book value, enterprise value, etc. when they invest their capitals. The size of the company value is measured by the stock price traded

* Corresponding author.

E-mail address: yuniningsih@upnjatim.ac.id (Y. Yuniningsih) 
in the capital market. Company value can also be determined using the valuation ratio. The company value assessment ratio can use price earnings ratio (PER), dividend yield, dividend payout ratio (DPR) or market to book value ratio (MBV) (Sudana, 2011). Many factors are needed to be considered in investing both fundamental and non-fundamental factors. According to Handriani and Irianti (2015) investment activity is carried out by money spent on a certain assets hoping to get profits from the planted capital. According to Miller and Modigliani (1961) and Dixit et al. (1994) investment opportunity is estimated by the market as a better future for the company and it can be seen as the company's valuation. Information in Investment Opportunity, such as the company's ability to make a profit, the company's operating cash flow, company growth, etc. are considered for the capital market evaluation. This information is used as a guideline for investors to make investment decisions for certain companies. Investors in making investment decisions cannot be separated from investment objectives. Investment objectives according to Fahmi (2015) are categorized in four sections; namely a. creation of sustainability, b. creation of maximum profit, c. creation of prosperity of shareholders, $d$. contribute to national development.

According to Brealey et al. (2008) funding decisions are the responsibility of financial managers in obtaining the funds needed to finance investments and operations. Husnan (2008) also stated that funding decisions are associated with the form and composition of funding that the company will use. Funding can be obtained from internal equity, external equity and external finance. Funding decisions are often referred to as capital structures. Capital structure according to Sudana (2011) is related to the company's long-term expenditure measured by comparison of long-term debt with own capital. According to Kasmir and Lainnya (2010) the ratio used in measuring capital structure is debt to asset ratio, debt to equity ratio, long term debt to equity ratio, time interest earned and fixed charge coverage.

According to Agrawal and Jayaraman (2004), dividend policy is arranged based on the proportion of company profits that can be distributed to shareholders and the retained earnings used for the reinvestments. According to Nwamaka (2017) optimal dividend policy is to maximize the company's stock price with the aim of maximizing the value of the company. Factors that influence dividend policy According to Van Horne (2007) are legal rules, corporate funding needs, liquidity, borrowing ability, limits on debt contracts, etc. (Gumanti, 2013). Donaldson (1961) is believed to be the first who developed a pecking order theory that discussed companies based on internal funding in paying dividends and funding investments. This theory states that capital structure is much influenced by the opportunity of company growth which is characterized by investment. When a company experiences growth, the company will need more funding. Funding sources can be obtained from internal funding or external funding. Internal funding sources are obtained from internal equity from retained earnings. Medium external funding sources can be obtained from external finance and external equity. External finance is obtained from debt while external equity is obtained from the issuance of new shares. Donaldson (1961) also states the use of retained earnings is more desirable because it can minimize costs compared with external funding sources. Pecking order theory describes the sequence of using funds based on the cost of the smallest of each source of funds. The company will be better off using funds from retained earnings, if retained earnings do not meet, they will use debt, and if the debt has not met, the company will issue shares. Signaling theory from Modigliani and Miller (1958) is based on the assumption that actions taken by company management can provide instructions to investors about the company's prospects. This was also stated by Melewar (2008) that the company can capture information signals about hidden attributes of stakeholders. Signals give investors a variety of signs so they can provide an overview of the company's prospects in the future. The signal can be in the form of various decisions taken by company management or company financial statements regarding profitability, solvency, leverage, dividends, liquidity investments, company performance and others. Based on the signal received by the investor, investors can make buy/sell decisions. Various results of empirical studies show that many variables affect firm value. According to Budagaga (2017), the dividend payment variable affects firms' value. According to Rizqia and Sumiati (2013) firm's value is influenced not only by dividend policy but also by investment opportunities. According to Arifah and Roifah (n.d.) firm value is influenced by 
funding decisions, investment decisions and dividend policies. Fundamental variables of 3 (three) main functions in financial management, which is funding, investment and dividends, directly affect the value of the company. The differences of this study with previous studies is that the three variables of investment are assumed to have interdependence of funding and dividends in affecting the firm's performance. The three variables of financial management act as endogenous and exogenous variables that act as independent variables. There are other exogenous variables acting as control variables that have an indirect effect on company performance such as profitability, ownership, company size, company growth and liquidity.

Funding decisions are related to fundraising which are used to finance investment activities and company operations. Decision making on funding sources must pay attention to the benefits and costs incurred (Yuniningsih et al., 2017; Yuniningsih, 2017; Yuniningsih et al., 2018). Benefits and costs are considered because each funding source has different consequences and characteristics. As revealed in the pecking order theory hypothesis (Myers, 1977; Myers \& Majluf, 1984) fund source includes internal equity, external finance and external equity. External finance funding is carried out, if funding from internal equity is insufficient. According to Myers (1977) balancing theory states that the use of debt in a certain proportion will increase the value of the company, after passing the optimal limit, the addition of debt usage will reduce the value of the company. Corporate funding is also closely related to many factors. The greater the investment made, the greater the amount of debt funding. According to Fama and French (2002), based on pecking order theory predictions, the balance of financing costs encourages companies that have large investments tend to have large debt funding as well. On the other hand, the greater the dividends paid, the greater the amount of funding coming from debt. Fama and French (2002) dividends become unattractive if companies make high investments. According to Baskin (1989) and Adedeji (1998) dividends have a positive effect on funding from debt. On the other hand, the greater the funding from debt, the higher the investment made. Pecking order theory states that debt will increase when investment exceeds retained earnings and vice versa (Fama \& French, 2002). On the contrary, the more profits are distributed dividends, the smaller the funds available for investment. The results of the study by Baskin (1989) and Adedeji (1998) show that the dividend payout ratio has a negative effect on investment. The results of the study by Baskin (1989) indicate that profitability has a positive effect on investment. The higher the size of the company, the greater the investment made and the greater it is to get funds from debt. The greater the growth of the company shows an increase in sales thus affecting the high levels of investment.

Other linkages are greater the higher the debt financing of dividends paid. The resulting study (Adedeji, 1998) showing financial leverage is positively related to dividends. The more funding from debt, the more funds are available and the higher the dividends paid. The higher the investment made, the lower the dividend paid because most of the funds, especially from profits, are used for investment (Barclay et al., 1995) if the growth of the company is high, significant amount of funds are needed for investment and lower dividends are paid. According to Adedeji (1998) there is a negative relationship between investment and dividend payout ratio. The larger the size of the company the more dividends will be paid and vice versa. Based on the explanation above, it can be concluded that the higher the investment of the company, the greater the external finance or leverage needed and the smaller the dividends distributed and vice versa. This is accomplished because internal equity funds are insufficient to finance investments so that additional funds need to be made from external finance, especially from the leverage. Another consequence is that the higher the investment, the more profit that is internal equity will be used to fund investment. Consequently smaller dividends are distributed and vice versa. Funding policies are associated with leverage or external finance must be made as detailed as possible because the decision of leverage will have an impact on the value of the company (Megginson, 1997). The tradeoff theory model explains the use of debt at a certain level will increase firm value. But after passing the maximum point, adding debt will reduce the value of the company. The decrease in the value of the company is caused by the profit from using debt is less than or not proportional to the increase in the cost of financial distress and agency problems (Megginson, 1997). The exogeneous 
variables acting as a control variable in the leverage equation are profitability, ownership, and liquidity. Investment policy must be performed with care because it will determine the value of the company. According to Yuniningsih et al. (2018) and Yuniningsih (2017) short and long-term investment decisions must take into account internal and external factors. As stated by Miller and Modigliani (1961) and Dixit et al. (1994) investment opportunity is an important part of the value of the company. Exogeneous variables that act as control variables on investment equations are profitability and company growth. Dividend policy related to dividend payments is part of the company's supervision of shareholders. According to Agrawal and Jayaraman (2004) dividend policy is a financial management function in determining the proportion of profits distributed to shareholders and retained earnings. The results of the study by Budagaga (2017) show there is a significant relationship between dividend payments and company value. Exogeneous variables act as control variables on dividends are profitability, company size, and company growth.

\section{The proposed study}

This study focuses on the relationship of the three main functions of financial management in determining firm values, especially companies incorporated in the Jakarta Islamic Index (JII). Data on average company value, leverage, investment, and dividend from 30 companies incorporated in the JII 2013 - 2016 period are as follows.

Table 1

Average from company value, Leverage. Investment and dividend JII 2013-2016

\begin{tabular}{lcccc}
\hline Information & 2013 & 2014 & 2015 & 2016 \\
\hline Company value & 5.9 & 2.34 & 2.14 & 1.32 \\
Leverage & 0.963 & 1.777 & 1.073 & 1.154 \\
Investment & -62.083 & -7.425 & 40.351 & 23.767 \\
Dividend & 0.438 & 0.748 & 0.411 & 0.382 \\
\hline
\end{tabular}

Source: htttp://www.idx.co.id/idid/

The company's average performance in 2013 was high over the following years because after 2013 it continued to decline until the end of the observation period. Leverage and investment during the observation period tend to increase. On the contrary, dividends tend to decrease from 2014 to 2016. Based on the problems above, this research examines how the three main functions in financial management influence each other in determining firm value. Based on the explanation above, this study hypothesizes

H1. Funding interdependence has a positive effect on company value.

H2. Investment interdependence has a positive effect on company value.

H3. Dividend interdependence has a positive effect on company value.

\section{Method}

This research is empirical research using secondary data from the financial statements. The population consists of 30 companies registered in the Jakarta Islamic Index for four periods from 2013 to 2016. Sampling is based on purposive sampling using certain criteria. One of the criteria for sampling is the required data must be in the company's financial statements during the study period. After tabulating the data, 16 companies did not have the data needed for research in the financial statements. So the number of samples reaches to 14 companies. The next step is to test for normality. When testing for normality, data from 3 companies is extreme data so three companies must be excluded. Final data used as research samples were 11 companies. The overall data used in this study in each variable is 44 . This data is obtained from the number of companies multiplied by the length of the study period which is four years from 2013 to 2016. While the schematic framework of the model in this study is shown in Fig. 1. The analysis method uses two-stage multiple linear regression (2SLS) by using variable identification first based on the schematic framework shown in Fig. 1. There are four structural equations, namely the equation of company value, leverage, investment, and dividend. Variable leverage, investment, and dividends act as endogenous variables in the equation itself and also as extragenous variables 
in other equations. Leverage, investment, and dividends are variables that act as endogenous variables and at the same time show the interdependence of these three variables in influencing company value.

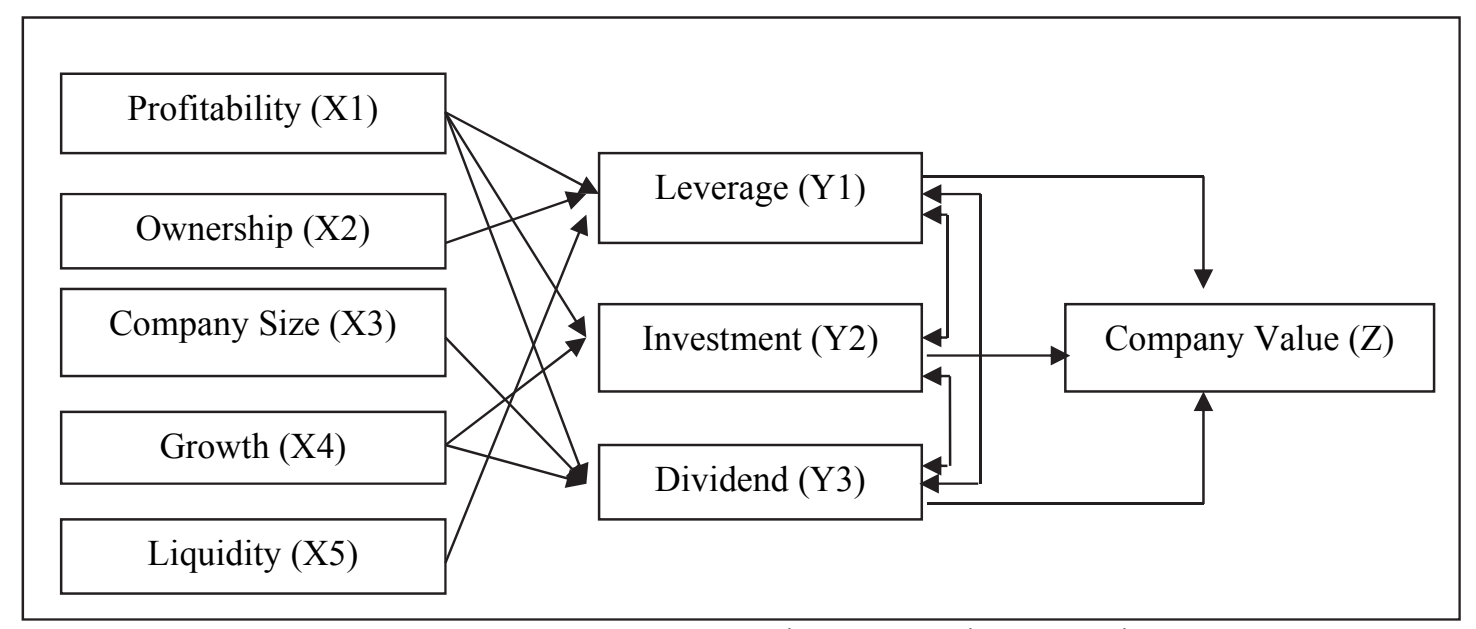

Fig. 1. Conceptual Framework Research

The other variables in each equation besides the variables leverage, investment, dividend and company value act as control variables of each equation. Control variables in this study include profitability, ownership, company size, company growth, and liquidity. The formulation of the four structural equations in this study is as follows

Leverage: $\quad Y_{1}=a_{0}+a_{1} Y_{2}+a_{2} Y_{3}+a_{3} X_{1}+a_{4} X_{2}+a_{5} X_{5}+\varepsilon_{1}$

Investment: $\quad Y_{2}=b_{0}+b_{1} Y_{1}+b_{2} Y_{3}+b_{3} X_{1}+a 4 X_{4}+\varepsilon_{2}$

Dividend: $\quad Y_{3}=c 0+c_{1} Y_{1}+c_{2} Y_{2}+c_{3} X_{1}+c 4 X_{3}+c_{5} X_{4}+\varepsilon_{3}$

Firm value: $\quad Z=d 0+d_{1} Y_{1}{ }^{\prime}+d_{2} Y_{2}{ }^{\prime}+d_{3} Y_{3^{\prime}}+\varepsilon 4$

where

$\mathrm{Y} 1=$ Leverage

$\mathrm{Y} 2$ = investment

$\mathrm{Y} 3=$ dividend

$\mathrm{Z}$ = company value

$\mathrm{X} 1=$ Profitability

$\mathrm{Y}^{\prime}$ ', Y', $\mathrm{Y}^{\prime}$ ' = regression results from $\mathrm{Y} 1, \mathrm{Y} 2$, and $\mathrm{Y} 3$

$\mathrm{a}, \mathrm{b}, \mathrm{c},=$ coefficients of the regression

$\varepsilon_{1}, \varepsilon_{2}, \varepsilon_{3}$ and $\varepsilon_{4}=$ error term

$$
\begin{aligned}
& \text { X2 }=\text { Ownership } \\
& \text { X3 }=\text { company size } \\
& \text { X4 }=\text { company growth } \\
& \text { X5 }=\text { liquidity }
\end{aligned}
$$

The analytical tool used is 2SLS (two least squared) provided that each equation must meet the specified identification criteria. Identification is intended to determine the relationship between endogenous variables between variables $\mathrm{Y}_{1}$ (Leverage), $\mathrm{Y}_{2}$ (Investment), $\mathrm{Y}_{3}$ (dividend) and $\mathrm{Z}$ (company value). Identification tests are also used to find out whether the equation is in one of three conditions, namely Under-identified, Exactly-identified, Over-identified, (Sumodiningrat, 1999). Equations can meet the requirements for 2 SLS analysis if the identification test results are in exactly or over-identified. Based on the research conceptual framework above, the identification test results are presented in Table 2. Identification test results from Table 2 show that this study is feasible to use 2SLS because it meets the specified requirements.

\section{Table 2}

Identification Test

\begin{tabular}{cccccc}
\hline No & Equation & $\left(\mathrm{K}-\mathrm{K}^{*}\right)$ & $(\mathrm{G}-1)$ & Results & Identification \\
\hline 1 & $\mathrm{Y} 1$ & $9-6$ & $4-1$ & $3=3$ & exactly identified \\
2 & $\mathrm{Y} 2$ & $9-5$ & $4-1$ & $4>3$ & over-identified \\
3 & $\mathrm{Y} 3$ & $9-6$ & $4-1$ & $3=3$ & exactly identified \\
4 & $\mathrm{Z}$ & $9-4$ & $4-1$ & $5>3$ & Over-identified \\
\hline $\mathrm{K}=$ number of variables in the model, & $\mathrm{K}^{*}=$ & Number of variables in the equation, $\mathrm{G}=$ Number of equations &
\end{tabular}




\section{Results and Discussion}

\subsection{Normality Test Analysis of leverage, investment, dividend and company value}

This normality test uses the One-Sample Kolmogorov-Smirnov Test.

Table 3

Normality Test Results of leverage, investment, and dividend equations

\begin{tabular}{|c|c|c|c|c|}
\hline Information & Residual 1 & Residual 2 & Residual 3 & Residual 4 \\
\hline $\mathrm{N}$ & 44 & 44 & 44 & 44 \\
\hline \multicolumn{5}{|l|}{ Normal parameter } \\
\hline Mean & .00000 & .00000 & .00000 & .00000 \\
\hline Std Deviation & .4633483 & 8.8771448 & .1673532 & 2.04716286 \\
\hline \multicolumn{5}{|l|}{ Most Extreme Differences } \\
\hline Absolute & 164 & 106 & 108 & .092 \\
\hline Positive & 164 & 164 & .063 & .092 \\
\hline Negative & -.085 & -.070 & -.108 & -.062 \\
\hline Test Statistic & .164 & .106 & 108 & .092 \\
\hline Asymo Sig (2-tailed) & $.004^{\mathrm{c}}$ & $.200^{\mathrm{c}, \mathrm{d}}$ & $.200^{\mathrm{c}, \mathrm{d}}$ & $.200^{\mathrm{c}, \mathrm{d}}$ \\
\hline Monte Carlo Sig (2-tailed)sig & $.166^{\mathrm{d}}$ & $.659^{\mathrm{e}}$ & $.653^{\mathrm{e}}$ & $.820^{\mathrm{e}}$ \\
\hline $99 \%$ Confidence interval Lower Bound & .156 & 646 & .640 & .810 \\
\hline Upper Bound & .175 & .671 & .665 & .830 \\
\hline
\end{tabular}

a. Test distribution is Normal.

The results of the normality test on the leverage equation show that the data is normally distributed, then it is feasible to do the classic assumption test. Three classic assumption tests, which is multicollinearity, heteroscedasticity and autocorrelation on the leverage equation in this study are as follows:

\subsection{Classical assumption tests}

\subsubsection{Multicollinearity tests}

\section{Table 4}

Multicollinearity test results for Leverage, Investment, Dividend, Company value

\begin{tabular}{|c|c|c|c|c|}
\hline \multirow[t]{2}{*}{ Model } & \multicolumn{4}{|c|}{ Collinearity Statistics VIF } \\
\hline & Leverage(Y1) & Investment (Y2) & Dividend (Y3) & Company Value $(\mathrm{Z})$ \\
\hline (Constant) & - & - & - & - \\
\hline Profitability & 3.010 & 2.000 & 1.630 & - \\
\hline Ownership & 1.191 & & - & - \\
\hline Company size & - & & 1.224 & - \\
\hline Growth & - & 1.293 & 1.266 & - \\
\hline Liquidity & 3.031 & & - & - \\
\hline Leverage & - & 1.734 & 2.099 & 2.343 (Predicted) \\
\hline Investment & 1.205 & & 1.185 & 1.557 (Predicted) \\
\hline Dividend & 1.530 & 1.528 & - & 2.653 (Predicted) \\
\hline
\end{tabular}

The first classical assumption is multicollinearity. Each exogeneous variable of leverage equation, investment equation, dividend equation and company value equation shows $\mathrm{VIF}<10$. Therefore, each exogenous variable from each equation shows no multicollinearity or no correlation between exogenous variables in this study.

\subsubsection{Autocorrelation tests}

Table 5

Test results of autocorrelation equation Leverage, Investment, Dividend, Company value

\begin{tabular}{ccccc}
\hline \multirow{2}{*}{ Model } & \multicolumn{4}{c}{ Equation } \\
\cline { 2 - 5 } & Leverage (Y1) & Investment (Y2) & Dividend(Y3) & Company Value (Z \\
\hline Durbin-Watson & 1.825 & 2.216 & 2.165 & 1.949 \\
\hline
\end{tabular}

Although the data is not a time series but this equation is carried out by an autocorrelation test. There is autocorrelation if the Durbin-Watson (DW) value is between the value of $\mathrm{dL}<\mathrm{d}$ or $\mathrm{d}<4$-dL (auto 
positive correlation) or if the value of $\mathrm{dU}<\mathrm{d}<4-\mathrm{dU}$ (negative autocorrelation). The Durbin Watson value in the leverage equation shows a value of 1.825 , while the dL table value is 1.2269 and the $\mathrm{dU}$ table is 1.8378 , the variable number is 6 , and the sample is 44 , so it is at position 6.44 . DW values are between $\mathrm{dL}$ values, and dU means to be in the area of doubt. Although it is located in the area of doubt, it can still be used because the data is not time series but the purposive sampling. In the investment equation the value of Durbin Watson shows a value of 2.216 while the value of dL table is 1.2769 and $\mathrm{dU}$ table is 1.7777 with the number of 5 variables and sample 44, so the table is at the position 5.44. While the $4-\mathrm{dU}=4-1.777=2.2223$, so that 2.216 is between the values of $\mathrm{dU}(1.777)$ and $4-\mathrm{dU}$ (2.2223). Based on these results there is no autocorrelation on the investment equation in this study. The dividend equation has a Durbin Watson value of 2.165 while the dL table value is 1.2269 and the $\mathrm{dU}$ table is 1.8378 . The number of variables is 6 with 44 samples, so the DW table is located at position 6.44. The 4-dU value in this equation is $4-1.8378=2.1622$ and is between the 4-dU and 4-dL so that this equation is in the area of positive doubt. Although it is located in the area of doubt, it can still be used because the data is not time series but the purposive sampling. The value of Durbin Watson in the equation of firm value shows the scores of 1.949 while the value of dL table is 1.3263 and the dU table is 1.7200 . The number of variables in this equation is 4 , and the sample is 44 , so the DW table is located at position 4.44. The 4-dU value in this equation is equal to $4-1.7200=2.2800$ and is between the $\mathrm{dU}$ and 4-dU values so that it shows no autocorrelation. The four equations can be concluded that this study meets the requirements of classical assumptions, especially regarding free autocorrelation. The next classic assumption test is heteroscedasticity test.

\subsubsection{Heteroscedasticity test}

Table 6

Test results of heteroscedasticity equation Leverage, Investment, Dividend, Company value

\begin{tabular}{|c|c|c|c|c|}
\hline \multirow[t]{2}{*}{ Model } & \multicolumn{4}{|c|}{ Significance } \\
\hline & Leverage (Y1) & Investment (Y2) & Dividend (Y3) & Company Value (Z) \\
\hline Constant & .612 & .011 & .001 & .000 \\
\hline Profitability & .724 & .158 & .227 & - \\
\hline Ownership & .109 & - & - & - \\
\hline Company size & - & - & .236 & - \\
\hline Growth & - & .794 & .784 & - \\
\hline Liquidity & .575 & - & - & - \\
\hline Leverage & - & .073 & .765 & .499 (Predicted) \\
\hline Investment & .573 & - & .765 & .063 (Predicted) \\
\hline Dividend & .833 & .878 & - & .054 (Predicted) \\
\hline
\end{tabular}

Source: Process Data

Heteroscedasticity test in the study uses Glejser Test. In the leverage equation, equation investment, the dividend and company value equation show that the exogenous variable of each equation does not face with heteroscedasticity because the statistical results show the significance of more than 0.05 . Based on these three results, both multicollinearity, autocorrelation, and heteroskedasticity can be concluded that the four equations in this study fulfill the classical assumptions.

\subsubsection{Hypothesis Test Analysis}

The results of Table 7 show the equation of leverage has $\mathrm{R}^{2}$ value of 0.598 . R-square value on the investment equation shows a value of 0.100 or $10 \%$ which means that the independent variable in this equation can only contribute an explanation of $10 \%$ and the remaining $90 \%$ is explained by other variables. The contribution of the exogenous variable to this equation is very small. R-square on dividend equation shows a value of 0.349 or $34.9 \%$ which means that the exogenous variable in this equation can only contribute an explanation of $34.9 \%$ and the remaining $65.1 \%$ is explained by other variables. $\mathrm{R}$-square on the equation of the company value shows a value of 0.603 or $60.3 \%$ which shows that the exogenous variable in this equation can only give an explanation contribution of $60.3 \%$ and the remaining $39.7 \%$ is explained by other variables outside the predicted (Y1) leverage, Y2 ), dividend (predicted $\mathrm{Y} 3)$ to company value $(\mathrm{Z})$. 
Model suitability test or $\mathrm{F}$ test based on Table 7 shows that the three equations out of the four equations represent a significance F-value. The use of the research model in these three equations has precisely explained the variable changes from the value of leverage (Y1) in the leverage equation, dividend value (Y3) in the dividend equation and company value $(\mathrm{Z})$ in the company value equation. The value of $\mathrm{F}$ significance is the leverage equation of $000^{\mathrm{b}}$, the dividend equation is $.005^{\mathrm{b}}$, and the equation of the company value is $.005^{\mathrm{b}}$. Whereas the investment equation shows the $\mathrm{F}$ significance value of $.381^{\mathrm{b}}$ is greater than the significance limit used in the study that is 0.05 so that it does not meet the suitability of the model. This is not a big problem because the main objective of the research is to measure the overall performance of the company.

\section{Table 7}

Determinant test results $\left(\mathrm{R}^{2}\right)$ and simultaneous $(\mathrm{F})$ and Partial Test $(\mathrm{t})$ equation of Leverage, Investment, Dividend, Company value

\begin{tabular}{|c|c|c|c|c|c|c|c|c|}
\hline \multirow[t]{3}{*}{ Model } & \multicolumn{8}{|c|}{ Collinearity Statistics VIF } \\
\hline & \multicolumn{2}{|c|}{ Leverage } & \multicolumn{2}{|c|}{ Investment } & \multicolumn{2}{|c|}{ Dividend } & \multicolumn{2}{|c|}{ Company Value } \\
\hline & $\mathrm{t}$ & sig & $\mathrm{t}$ & sig & $\mathrm{t}$ & sig & $\mathrm{t}$ & sig \\
\hline R Square & - & .598 & - & .100 & - & .349 & - & .603 \\
\hline F (Sig) & - & .598 & - & $.381^{\mathrm{b}}$ & - & $.005^{\mathrm{b}}$ & - & $.005^{\mathrm{b}}$ \\
\hline \multicolumn{9}{|l|}{ t test } \\
\hline (Constant) & 4.462 & .000 & 2.654 & .011 & 1.859 & .071 & -4.082 & .000 \\
\hline Profitability & .162 & .872 & 1.440 & .158 & 3.363 & .002 & - & - \\
\hline Ownership & 1.088 & .283 & - & - & - & - & - & - \\
\hline Company size & - & - & - & - & -.436 & .665 & - & - \\
\hline Growth & - & - & -. 264 & .794 & -1.924 & .062 & - & - \\
\hline Liquidity & -4.378 & .000 & - & - & - & - & - & - \\
\hline Leverage & - & - & 1.843 & .073 & .568 & .573 & -.682 & .499 (Predicted) \\
\hline Investment & 2.793 & .008 & - & - & .038 & .970 & 3.108 & .003 (Predicted) \\
\hline Dividend & .091 & .928 & .154 & .878 & - & - & 3.066 & .004 (Predicted) \\
\hline
\end{tabular}

Table 7 presents the results of the partial test or t-test of the four equations, namely the equation of leverage, investment, dividend, and firm value although the main thing in this study is to analyze the value of the company from the variable leverage, investment, and dividend which in this equation acts as an exogenous variable. Based on the test results on the leverage equation, explains that Profitability $\left(\mathrm{X}_{1}\right)$ does not affect the positive direction to leverage $\left(\mathrm{Y}_{1}\right)$. Ownership $\left(\mathrm{X}_{2}\right)$ has no effect on the positive direction of leverage $\left(\mathrm{Y}_{1}\right)$. Liquidity or current assets $\left(\mathrm{X}_{5}\right)$ affect with the negative direction of leverage $\left(\mathrm{Y}_{1}\right)$. Investment $\left(\mathrm{Y}_{2}\right)$ influences with positive direction against leverage $\left(\mathrm{Y}_{1}\right)$ and finally, Dividend $\left(\mathrm{Y}_{3}\right)$ has no effect on the positive direction of leverage $\left(\mathrm{Y}_{1}\right)$.

The partial $(\mathrm{t})$ test results in the investment equation from Table 7 , explain that profitability $\left(\mathrm{X}_{1}\right)$ has no significant effect on investment $\left(\mathrm{Y}_{2}\right)$ when the level of significance is five percent. Company growth or Growth $\left(\mathrm{X}_{4}\right)$ has no negative influence on investment $\left(\mathrm{Y}_{2}\right)$. Leverage $(\mathrm{Y} 1)$ has no effect on the positive direction of investment $\left(\mathrm{Y}_{2}\right)$ and finally, Dividend $\left(\mathrm{Y}_{3}\right)$ has no effect on the positive direction of investment $\left(\mathrm{Y}_{2}\right)$. While the partial test results $(\mathrm{t})$ in the dividend equation shows profitability $\left(\mathrm{X}_{1}\right)$ influences positively on dividend $\left(\mathrm{Y}_{3}\right)$. Company size $\left(\mathrm{X}_{3}\right)$ has no effect in the negative direction on dividend (Y3). The growth of a company or growth $\left(\mathrm{X}_{4}\right)$ has no effect with negative direction towards dividend $\left(\mathrm{Y}_{3}\right)$. Leverage $\left(\mathrm{Y}_{1}\right)$ has no effect on the positive direction towards dividend $\left(\mathrm{Y}_{3}\right)$. Investment $\left(\mathrm{Y}_{2}\right)$ has no effect with a positive direction on dividend $\left(\mathrm{Y}_{3}\right)$. Based on the partial test results $(\mathrm{t})$ on the equation of the company value presented in Table 7 we realize that the predicted leverage has no effect on the negative direction to the Company Value $(Z)$ or rejected with a significance level of $0.499>0.05$ (level of significance). Investment ( $\mathrm{Y}_{2}$ predicted) influences the positive direction of the Company Value $(\mathrm{Z})$. Dividend ( $\mathrm{Y}_{3}$ predicted) influences with a positive direction on the Company Value (Z).

Interdependence variables in this study are leverage, investment and dividend and the three of them are decision variables in financial management. A financial manager in making funding decisions will determine whether it comes from own capital or foreign capital. Own capital is derived from retained earnings, paid-up capital and share issuance. While foreign capital is obtained from both short-term 
and long-term debt, after the financial manager gets funds, the funds are allocated to invest both short and long-term investments. Short-term investments include cash, short-term securities, debt, and inventories. While long-term investment is related to fixed assets in the form of land, buildings, brands, patents and others (Yuniningsih, 2017; Yuniningsih et al., 2018). After the fund is allocated in the investment, the investment must be operationalized to get a profit. After profits are obtained, the management must make a dividend decision. Dividend decisions are associated with the proportion of profits distributed to shareholders in the form of dividends and how much profit is allocated as retained earnings. In dividend decision making, a manager is required to be careful by considering several internal and external aspects (Hasna et al., 2018). The size of the dividends distributed is one indicator of investors in assessing the company's performance, and the company's performance will determine the value of the company. The leverage, investment, and dividend equations show the interrelations between the three independence variables. In the leverage, equation shows the investment variable affects leverage, but dividends do not affect leverage. This shows that dividend payments are not influenced by the amount of leverage and investment made by the company. The ability of a company to pay dividends is influenced by the company's ability to generate profits or profitability. The company's ability to generate profitability is shown by good corporate liquidity. Corporate liquidity plays an important role in influencing the company's leverage in a positive direction. But the size of the investment affects the amount of leverage. It shows that as long as investment funding can be financed with its capital, the company will use its capital as optimally as possible.

If funding from own capital in investing is deemed insufficient, then funding is carried out from foreign capital, especially from leverage. This can be related to the results on the investment equation. The investment equation shows that leverage and dividend variables do not affect the investment, because investment is mostly funded by own capital. Own capital can be obtained from retained earnings, paidup capital and share issuance. This shows that the company can generate profitability which is reflected by good liquidity. Although the company does or does not make dividend payments or loan funds, the company continues to invest. This is due to the decision of very good ownership. The results of this investment equation are also supported by the results of the dividend equation. Dividend equation shows that leverage and investment have no effect on dividends. Because dividend distribution can be paid from profits earned, moreover, companies can produce excellent profitability. Leverage is related to management's decision in determining how much funds are allocated in an investment. The balance sheet financial report shows that investment can be either short-term or long-term investment. Short term in the form of current assets and long-term investments in the form of fixed assets. These shortterm investments are in the form of cash, marketable short-term securities, debt and inventories (Hasna et al., 2018). While long-term investments can be in the form of land, machinery, patents, brands and others, funding of leverage not only determines the level of investment but also will determine the level of dividend distributed and will ultimately determine the performance of the company.

Hypothesis 1 on the company value equation, states that leverage has a positive influence on firm value. While the research results do not support this hypothesis, the results of this study indicate that leverage in a negative direction does not affect the value of the company. Hypothesis 1 explains that the greater the funding that comes from leverage, the greater the value of the company and vice versa. Company performance will determine the value of the company. One of the company's values can be measured by the high and low stock prices (Yuniningsih, 2017; Yuniningsih et al., 2018). But the results of the study in Table 7 show that leverage is negative and does not affect the value of the company. This is contrary to the research hypothesis. If funding that comes from leverage is high, the value of the company will be lowered. The influence of leverage on the value of the company is not by the trade-off theory or balancing theory (Myers, 1977). A trade-off theory explains the use of debt will determine the value of the company. The more debt to the optimal limit, the higher the value of the company. The optimal limit in question is when the debt interest rate equals the rate of return, or the amount of debt equals the amount of equity. When the optimal point is exceeded and the company continues to increase debt, the addition of the debt does not add to the value of the company but instead decreases the value 
of the company. This is due to a greater debt burden compared with the profit generated. Based on the explanation of the trade of theory, corporate debt is already at an optimal point. Additionally leverage a small part of the overall funding required, resulting in less leverage plays a major role in determining the performance of the company. Companies that are members of the Jakarta Islamic Index (JII) are likely to emphasize funding from their capital (internal equity and external equity) and not from foreign capital (external finance derived from leverage). Internal equity comes from retained earnings derived from the company's profitability. External equity came from the issuance of shares and paid-up capital in addition to other factors. The use of internal equity in consideration of the burden of the costs borne is smaller than the cost of leverage. Although leverage is in the optimal position. Established companies will find it easier to get large amounts of funds by issuing shares in the capital market. For companies that are already established, this is not a big problem even though the share issuance costs are greater than the funding costs that come from leverage. The use of funds derived from leverage must be careful because higher debt will result in bankruptcy of the company. Another reason leverage in this study does not play a big role in determining the value of the company; it is likely that many other variables play a more important role in determining the value of the company. These variables include company profitability, ownership, liquidity, investment policy, dividend policy and other variables outside the variables used in this study. The results of the research in hypothesis 1 are inconsistent by the pecking order theory proposed by Donaldson (1961). Pecking order theory describes the funding hierarchy is internal equity, external finance and external equity. Pecking order theory by Donaldson (1961) explained that Internal equity, especially from retained earnings, is used first in funding. If internal equity is insufficient, funding is made from external finance that comes from debt or leverage. If both of them cannot fulfill, then the new equity is obtained from the issuance of new shares and paid-up capital. The funding hierarchy is based on the costs incurred. The burden of internal equity costs is lower than external finance; external finance costs are lower than external equity. The results of this study are not consistent with the results of Anton (2016) where leverage had a positive effect on the value of the company. Meanwhile the results of this study are consistent with the results of Fenandar and Raharja (2012), funding decisions do not affect company value.

Hypothesis 2 states that investment has a positive effect on company value and the results of this study support the hypothesis. By the signaling theory (Ross, 1977) everything can give signals to other parties in the assessment. Signaling theory if it is associated with the investment, shows that the size of the investment greatly affects the size of the company. The good and bad value of the company will show the good and bad financial management of the company. Financial management deals with funding decisions, investment decisions, and dividend decisions. A good investment indicates the company is in good health. The soundness of the company shows good financial management and signifies a good future profit flow. Conversely, bad investment will give a signal that is not good for the value of the company as opinions (Miller \& Modigliani, 1961; Dixit et al., 1994) that investment opportunities are an important part of company value. Investment opportunities are interpreted by investors as a better future for high-value companies. Investors always see the development of the company's value before investing. This is because investors have a goal to improve welfare in the future. For investment objectives to be achieved, managers are required to make the best investment decisions by paying attention to internal and external factors (Yuniningsih et al., 2017). The results of this study are supported by some studies (e.g. Arifah \& Roifah, n.d.; Fenandar \& Raharja, 2012). The third hypothesis states that dividends have a positive influence on company value, the results of this study support the hypothesis. This shows the high and low dividends affect the high and low value of the company. The high and low dividends distributed will affect the perception of investors, both old investors and potential investors in valuing the company. During the investor perception of the performance is good then it will increase the value of the company. One measure of company performance is dividend distribution. The size of the dividend is one of the indicators in determining the stock price. Stock prices are one way to assess a company (Yuniningsih et al., 2018). Investors in assessing companies are not only influenced by fundamental factors based on financial statements but also influenced by non-fundamentals, especially the behavior of each investor (Hasna et al., 2018). The management of the company in making 
dividend policy must be more careful because it will affect the value of the company in the future. As stated by Amidu (2007), one of the most important financial decisions faced by company managers is making dividend policy decisions. The results of this study are supported by other studies (Budagaga, 2017; Anton, 2016; Fenandar \& Raharja, 2012) dividends have a positive influence on the value of the company. The results of this study are also by the signaling theory of theory (Ross, 1977). But the results of this study are not by irrelevant theory from Miller and Modigliani (MM). The irrelevant theory states that dividend policy does not affect the value of the company. The value of the company is not determined by the income derived from dividends, but the accuracy in choosing the optimal investment.

\section{Conclusion}

This study has discussed the interdependence of 3 decisions in financial management that affect company value. The three financial management decisions are leverage, investment, and dividends. The three decisions affect each other where each variable acts as an endogenous and exogenous variable in another equation. While the variable value of the company acts as an endogenous variable that is directly affected by exogenous variables namely leverage, investment, and dividends, the results of the study show that leverage did not affect the value of the company (the results of the study of hypothesis 1). This happens because the investment and dividend variables play a more important role in determining the value of the company (the results of research from hypotheses 2 and 3 ). The company's ability to generate profits and ease of access in the capital market in issuing shares played a major role in financing non-debt investments. Likewise in dividend distribution the company can pay with funding from retained earnings. The ability of the company to make investments and dividends will give a signal to investors in assessing the company. This has encouraged the company to be very careful in making financial policies by considering many fundamental and non-fundamental factors.

\section{References}

Adedeji, A. (1998). Does the pecking order hypothesis explain the dividend payout ratios of firms in the UK? Journal of Business Finance \& Accounting, 25(9-10), 1127-1155.

Agrawal, M., \& Jayaraman, A. (2004). Mechanism of dividend payment and leverage policy. Journal of Accounting Research, 21(2).

Anton, S. G. (2016). The impact of leverage on firm growth. Empirical evidence from Romanian listed firms. Review of Economic and Business Studies, 9(2), 147-158.

Arifah, D. A., \& Roifah, S. (n.d.). The effect of investment decision, funding decision and dividend policy on corporate value.

Barclay, M. J., Smith, C. W., \& Watts, R. L. (1995). The determinants of corporate leverage and dividend policies. Journal of Applied Corporate Finance, 7(4), 4-19.

Baskin, J. (1989). An empirical investigation of the pecking order hypothesis. Financial Management, 2635.

Beik, I. S., \& Fatmawati, S. W. (2014). Pengaruh Indeks Harga Saham Syariah Internasional Dan Variabel Makro Ekonomi Terhadap Jakarta Islamic Index. Al-Iqtishad: Jurnal Ilmu Ekonomi Syariah, 6(2), 155178.

Brealey, R. A., Myers, S. C., \& Marcus, A. J. (2008). Dasar-Dasar Manajemen Keuangan Perusahaan. Edisi Kelima. Jilid, 2.

Budagaga, A. (2017). Dividend Payment and its Impact on the Value of Firms Listed on Istanbul Stock Exchange: A Residual Income Approach. International Journal of Economics and Financial Issues, 7(2), 370-376.

Dixit, A. K., Dixit, R. K., Pindyck, R. S., \& Pindyck, R. (1994). Investment under uncertainty. Princeton university press.

Donaldson, G. (1961). Corporate debt capacity.

Fahmi, I. (2015). Pengantar Teori Portofolio dan Analisis Investasi. Bandung: Alfabeta Bandung.

Fama, E. F., \& French, K. R. (2002). Testing trade-off and pecking order predictions about dividends and debt. The Review of Financial Studies, 15(1), 1-33.

Fenandar, G. I., \& Raharja, S. (2012). Pengaruh keputusan investasi, keputusan pendanaan, dan kebijakan 
dividen terhadap nilai perusahaan. Fakultas Ekonomika dan Bisnis.

Gumanti, T. A. (2013). Kebijakan Dividen Teori, Empiris dan Implikasi.

Handriani, E., \& Irianti, T. E. (2015). Investment Opportunity Set (IOS) Berbasis Pertumbuhan Perusahaan dan Kaitannya Dengan Upaya Peningkatan Nilai Perusahaan.

Hasna, N. A., Nizarudin, B., \& Sugeng, W. (2018). Financial Performance Measurement Of With Signaling Theory Review On Automotive Companies Listed In Indonesia Stock Exchange, 1(2), 167-177.

Husnan, S. (2008). Portofolio dan Implikasinya Bagi Manajemen Keuangan. Edisi Ke Dua, BPFE.

Kasmir, B., \& Lainnya, L. K. (2010). Jakarta: PT. RajaGrafindo Persada.

Megginson, W. L. (1997). Corporate finance theory. Addison-Wesley.

Melewar, T. C. (2008). Facets of corporate identity, communication and reputation. Routledge.

Miller, M. H., \& Modigliani, F. (1961). Dividend policy, growth, and the valuation of shares. The Journal of Business, 34(4), 411-433.

Modigliani, F., \& Miller, M. H. (1958). The cost of capital, corporation finance and the theory of investment. The American Economic Review, 48(3), 261-297.

Myers, S. C. (1977). Results for 'Determinant of Corporate Borrowing. Journal of Financial Economic. No 5,pp 147-155.' in 'All Documents'; did you mean determinants of corporate borrowing. journal of financial economic. no 5,pp 14-15.? The Journal of Finance, 39(3), 574-592.

Myers, S. C., \& Majluf, N. S. (1984). Corporate financing and investment decisions when firms have information that investors do not have. Journal of Financial Economics, 13(2), 187-221.

Nwamaka, O. C. (2017). Effect of Dividend Policies on Firm Value: Evidence from quoted firms in Nigeria. International Journal of Management Excellence, 8(2), 956-967.

Rizqia, D. A., \& Sumiati, S. A. (2013). Effect of Managerial Ownership, Financial Leverage, Profitability, Firm Size, and Investment Opportunity on Dividend Policy and Firm Value. Research Journal of Finance and Accounting, 4(11), 120-130.

Ross, S. A. (1977). The determination of financial structure: the incentive-signalling approach. The Bell Journal of Economics, 23-40.

Sudana, I. M. (2011). Manajemen Keuangan Perusahaan Teori dan Praktik. Erlangga. Jakarta.

Sumodiningrat, G. (1999). Ekonometrika Pengantar, Edisi Pertama, Cetakan Kelima, Penerbit BPFE. Yogyakarta.

Van Horne, J. (2007). Y WACHOWICZ JR, John. Fundamentos de Administración Financiera. España: $E d, 11$.

Yuniningsih, Y. (2017). Seberapa Besar Kepemilikan Saham Berperan Dalam Penentuan Nilai Perusahaan Dengan Tinjauan Agency Theory. Jurnal Darussalam: Jurnal Pendidikan, Komunikasi Dan Pemikiran Hukum Islam, 9(1), 107-115.

Yuniningsih, Y., Hasna, N. A., Wajdi, M. B. N., \& Widodo, S. (2018). Financial Performance Measurement Of With Signaling Theory Review On Automotive Companies Listed In Indonesia Stock Exchange. IJEBD (International Journal Of Entrepreneurship And Business Development), 1(2), 167-177.

Yuniningsih, Y., Lestari, V. N. S., Nurmawati, N., \& Wajdi, B. N. (2018). Measuring Automotive Company's Capabilities in Indonesia in Producing Profits Regarding Working Capital. Jurnal Terapan Manajemen Dan Bisnis, 4(1), 67-78.

Yuniningsih, Y., Widodo, S., \& Wajdi, M. B. N. (2017). An analysis of Decision Making in the Stock Investment. Economic: Journal of Economic and Islamic Law, 8(2), 122-128.

Zutter, C. J., \& Gitman, L. J. (2011). Principles of Managerial Finance, Brief. Pearson Higher Ed.

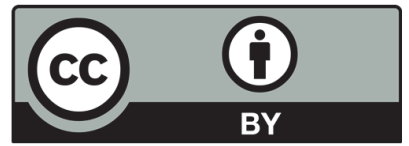

(C) 2019 by the authors; licensee Growing Science, Canada. This is an open access article distributed under the terms and conditions of the Creative Commons Attribution (CC-BY) license (http://creativecommons.org/licenses/by/4.0/). 